\title{
Dugong in the Account of Stamford Raffles
}

\author{
Daya Negri Wijaya \\ History Department \\ State University of Malang \\ Malang, Indonesia \\ Corressponding email: daya.negri.fis@um.ac.id \\ Neni Wahyuningtyas \\ Department of Social Studies \\ State University of Malang \\ Malang, Indonesia
}

\begin{abstract}
The mode of empiricism leads anyone to construct a knowledge based on people's experience. One of the empiricists is Stamford Raffles. However, he was a colonizer in Java and Bengkulu during the beginning of the nineteenth century but he also elaborated the biogeography of flora and fauna of Java and Sumatra. He found and discussed the anatomy and the spread of some flowers and animals, like Rafflesia Arnoldi and dugong. Interestingly, he asked Everard Home to provide him some extracts related to Dugong. As a marine mammal, Raffles assumed dugong was measured eight feet and a half in length. Dugong was found in the shallow inlets of the sea. It was moving and spreading into various areas because of its foods which was submarine algae. This paper intends to interpret his examination on dugong. It also compares and contrasts the species of the mammalian order Sirenia (sea cows), which are the dugong as Raffles found and the other manatees. This study used the library research. The library research was useful to collect the written data. All major sources of Raffles' work and dugong are available in online and offline libraries. This study used some steps mainly in collecting sources, reading critically, making a note, analyzing the data, and concluding the data analysis.
\end{abstract}

\section{Keywords-Dugong, raffles, Singapore, biogeography}

\section{INTRODUCTION}

Raffles was well known as a political figure. He was a lieutenant governor of Java and Bengkulu. The financial crisis during his authority in Java led the board of EIC in London to call him back. Raffles with his disappointed feeling left Java on 25 March 1816. He was welcomed by some people especially some noblemen. Princess Charlotte, one of the royal families, was familiar with Raffles. He gave her a beautiful table from Java. His present was really famous in London, therefore, Princess Charlotte's grandmother, King George III's wife, invited him to the palace.

He then was well-known in the circle of London intellects after his book entitled "History of Java" was published. Seeing the engagement of Raffles and the royal family, the board of directors of East India Company opened his complicated case around 3.5 years (a charge of Gillespie and his recalling to England). They apologized for the past mistreatment. The directors confirmed the place of Raffles in Bengkulu (Collis, 2000:100).

Raffles arrived in Bengkulu on 22 March 1818 after facing a voyage around 4 months. He spent his time to read Marsden's work and collected some information in Sumatera. He issued the same policy when he had a power in Java. The forcing policy and slavery were abolished by giving a freedom certificate. He believed that gambling and cockfighting contributed to social disharmony. Raffles claimed that those activities affected some crimes like killing and robbery (Raffles, 1824:34-36). He believed that it was prominent to keep the safety of Southeast Asian trade. He pointed the Malacca strait as a strategic area. The Prince of Wales' Island was far from Malacca strait and Bengkulu was near from the Indian Ocean and Sunda strait. He looked out into Tumasik Island, then called Singapore. Raffles, through his diplomatic ability, succeeded to gain a license in building Singapore from Sultanate Johor by paying the land rent.

However, he spent his much time on the political affairs but he also created a community of zoologists and botanists in Bengkulu where he found Rafflesia Arnoldi with Dr. Arnold. His habitual activity in writing letters helped him to find some new species of flora and fauna. Furthermore, he also found a marine mammal called dugong when he stayed in Singapore in June 1820. People will be interested to read his curiosity on dugong. He had a correspondence with Everard Home concerning on dugong. Therefore, this paper tries to interpret his examination on dugong related to its anatomy and its biogeography.

\section{METHOD}

This study tended to use library research. This study had used some steps mainly in reading critically and making a note. It considered Raffles' work on dugong which was "Some Account of Dugong" (1820). It also considered Everard Home's letters to him like: "Particulars Respecting the Anatomy of the Dugong, Intended as a Supplement to Sir T. S. Raffles' Account of that Animal" (1820); "On the Milk Tusks and Organ of Hearing of the Dugong" (1820); "On the Peculiarities that distinguish the Manatee of the West Indies from the Dugong of 
the East Indian Seas" (1821), and "An Account of the Skeletons of the Dugong, Two-Horned Rhinoceros, and Tapir of Sumatra, Sent to England by Sir Thomas Stamford Raffles, Governor of Bencoolen" (1821). The researchers also used some secondary sources to interpret Raffles examination on dugong, for example, Brown's work of "The Sirenia" (1878). In addition, this study analyzed and compared the findings with some secondary sources. Finally, the author would conclude the analysis shortly.

\section{FINDING AND DISCUSSION}

A new way of knowing appears in the day of Raffles. The intellects make an effort to free from past superstitions and misconceptions. They look at the world with fresh eyes and a receptive mind (Quilty, 1998:17). They tend to follow the mode of empiricism. According to Wijaya (2013:20), an empiricist tends to have knowledge based on experience and observation. Likewise, this tendency, Raffles also conducts a similar effort to know the anatomy of dugong. He meets some dugongs at Singapore. He examines the dugong with two French naturalists (Diard and Dwaucel). They work under his authority in Singapore.

Raffles (1820:175-6) reports his observation on dugong, in: "In form the dugong resembles the common cetacean, having, like them, a broad horizontal tail, and two pectoral fins without nails. The skin is smooth, thick, bluish above and whitish beneath, with a few remote and scattered hairs. The mammal (in the two male individuals examined) are small, and situated on the breast, immediately below the pectoral fins..."

Dugong obtains considerable length and size. The caudal paddle is crescent-shaped, and a large thick upper lip falls over the lower; the skin of the body, is thinly set with short prickly bristles; the anterior limbs or flippers are destitute of nails, and the eyes are very small. Dugong is a differ mammal compared to a manatee (Croft, 1860:3). Both animals have the different of tail shape. Their teeth differ in number and their form of the skeleton is similar. The stomach is different in the shape of the solid glandular part, and of the lateral pouches, but both animals feed upon fuci (Home, 1821:153).

Intriguingly, Croft (1860) also suggests that dugong produces the oil, originally from dugong's tears when it comes to the surface. It is useful for people's health. He asks his patient to use dugong oil regularly. His patient is weighed and placed on a certain class of diet. The results of the use of the oil, after the first week, astonishes the medical men, increase of weight, less difficulty of breathing, bloody expectoration checked, scarcely any profuse perspiration, diarrhea stopped, appetite better, in fact the results of the treatment are already apparent. He expresses his satisfaction in taking the oil.

\section{CONCLUSIONS AND SUGGESTIONS}

Biogeography, in general, is the meeting point between biology and geography. Therefore, biogeography seems to discuss the distribution of species in the geographical space and time. According to Crisci, et.al. (2003:2), biogeography should not be defined as simply as the study of the geographic distribution of living beings. However, they suggest that biogeography seems to include such subjects comprising geology, geography, and biology. This would consider a relationship between a species with other living beings. One of the species which will be discussed is dugong. Brown (1878:293) argues that "the first representative of the dugong makes its appearance on the east coast of Africa, along both shores of the Red Sea and the southern coast of Asia as far as Cochin China; taking in Borneo and the leading islands of the Indian Archipelago lying to the westward of the Straits of Lombok, which marks strictly the boundary line between the Indian fauna and that of the Australian region".

He also claims that dugong lives in the mouths of river and often to find it in the streams to a considerable distance from the coast, rarely being common in water of more than several fathoms depth. This statement seems to be supported that dugongs, in fact, are seagrass specialists and frequent coastal waters. Seagrass food is growing up in the coastal areas (Marsh, n.d.:1). Moreover, Raffles (1820:179) observes that "the food of the dugong appears to consist exclusively of fuci and submarine algae, which it finds at the bottom of shallow inlets of the sea. The position and structure of the mouth, enables the animal to browse upon these vegetables, much in the same manner as a cow in a meadow; and the whole structure of the masticating and digestive organs show it to be truly herbivorous".

At present, (Marsh n.d.:1) reports that "the dugong has a large range that spans some 37 countries and territories and includes tropical and subtropical coastal and inland waters from East Africa to Vanuatu, between about $26^{\circ}$ north and south of the Equator". Both Raffles and Home do not provide the distribution of dugong. However, Raffles (1820:180) succeeds to find dugongs when the sea is calmest, near the mouth of the Johor River, in the inlet of the sea between Singapore Island and the main. They are usually taken by spearing during the night, when the animals give warning of their approach by the snuffling noise they make on the surface of the water. Then, its activity is linked, by some people, to the folktale of (little) mermaid.

The folktale informs that there is a little mermaid, the younger daughter of the king of merpeople, in the undersea kingdom. She has fallen in love with a prince when she gets a chance to go to the surface at her fifteenth birthday. When she wants to come back, the storm wrecks the prince's ship. He is drowned and the little mermaid saves him, then brings him to the white beach where his guardians find him. She could not stop thinking of the prince. She slips away from her kingdom to meet the old witch. She wants to be a human and the witch fills her hope. However, she should pay her wish with her beautiful singing voice. She could not speak even a word. Then, she meets her handsome prince. The prince likes to be beside of the little mermaid. He tells her that he loves a woman who saves him on the wreck of ship. She cannot tell that the searched woman is her. She wait the prince until he marries another girl. She is broken heart and decides to be nothing like the bubble on the water. We could learn lots of values from this folktale, for example human beings are able to go beyond their destiny however they could not able to get all what they want to have. We could categorize this folktale to fable. According to Danandjaja (1986:98), fable is an animal tale containing mores, the lessons of the good and evil of people's attitude. The folktale of mermaid might teach humans beings that they could 
not only need the animal for their foods, works, and pets but also take the lessons from the animal tale.

Raffles (1820) also learns the meanings and values from the life of dugong through the wisdom of the Malays. For them, dugong is considered as a royal fish and all dugongs are owned by the king. The flesh is more highly prized than that of the buffalo or cow. Dugongs, like human beings, are categorized by male and female. The breasts of the adult females are said to be large. He realizes that the Malays make frequent allusion to this animal, as an illustration of maternal affection. Like the matriarchal society, the affection of the mother for its young is strongly marked. When the Malays succeed in taking a young one, they feel themselves certain of the mother, who follows it to the margin of the sea, and allows herself to be speared or taken with the greatest ease. The young have a short sharp cry, which they frequently repeat; and it is said they shed tears. These tears are carefully preserved by the common people as a charm, the possession of which is supposed to secure the affections of those to whom they are attached, in the same manner as they attract the mother to her young.

The Malays have considered the balance of micro and macro-cosmos to be the truly men. They are not only giving a lesson to others through the humanistic tale but also using the animal tale. This mixing wisdom might lead them to understand the state of nature. They will get a benefit of paying attention to the nature. They could transfer their social structure to their ancestors. They will be determined by the maternal rule continually.

Stamford Raffles is not only a colonizer but also a zoologist. He tends to learn regularly on some animals that he finds. At Singapore, he meets some dugongs. In the mode of empiricism, he investigates the anatomy of dugong. However, he asked two naturalists but he also concerns on its animal. Interestingly, he knows that dugong is not only a common mammal but also a royal fish for the Malays. They believe that dugong is depicted the maternal affection. Raffles learns how the mother takes a care of her child from the life of dugong.

\section{REFERENCE}

[1] Brown, A.E, 1878, "The Sirenia", The American Naturalist, vol. 12 (5): 291-298.

[2] Collis, M, 2000, "Raffles the Definitive Biography", Graham Brash, Singapore.

[3] Crisci, J.V, L. Katinas, \& P. Posadas, 2003, "Historical Biogeography", Harvard University Press, Cambridge \& London.

[4] Croft, J. M, 1860, “The Dugong Oil, Its Valuable Medicinal Properties for Consumption in Various Diseases", Unknown Publisher, London.

[5] Danandjaja, J, 1986, "Folklor Indonesia: Ilmu Gosip, Dongeng, dan lainlain”, Grafiti Press, Jakarta.

[6] Home, E, 1820, "On the Milk Tusks and Organ of Hearing of the Dugong”, Philosophical Transactions of the Royal Society of London, vol. 110: 144-155.

[7] Home, E, 1820, "Particulars Respecting the Anatomy of the Dugong, Intended as a Supplement to Sir T. S. Raffles' Account of that Animal", Philosophical Transactions of the Royal Society of London, vol. 110 315-323.

[8] Home, E, 1821, "An Account of the Skeletons of the Dugong, TwoHorned Rhinoceros, and Tapir of Sumatra, Sent to England by Sir Thomas Stamford Raffles, Governor of Bencoolen", Philosophical Transactions of the Royal Society of London, vol. 111, pp. 268-275.
[9] Home, E, 1821, "On the Peculiarities that distinguish the Manatee of the West Indies from the Dugong of the East Indian Seas", Philosophical Transactions of the Royal Society of London, vol. 111: 390-391.

[10] Marsh, H. (n.d.), "Dugong: Status Reports and Action Plans for Countries and Territories", United Nations Environment Programme World Conservation Monitoring Centre, Cambridge.

[11] Quilty, M.C, 1998, “Textual Empires: A Reading of Early British Histories of Southeast Asia”. Monash Asia Institute, Victoria.

[12] Raffles, T.S, 1820, "Some Account of Dugong", Philosophical Transactions of the Royal Society of London, vol. 110: 174-182.

[13] Raffles, T.S, 1824, "Statement of the Services", Cox \& Baylis, London.

[14] Wijaya, D.N, 2013, "The Dynamo of Civilised Society: John Locke on Nation and Character Building", Dissertation, The University of Sunderland, Sunderland. 